\title{
Sustainability Content on Oil and Gas Company Websites
}

\author{
Michel Coulmont ${ }^{1}$, Sylvie Berthelot ${ }^{1} \&$ Kim Thibault ${ }^{2}$ \\ ${ }^{1}$ Département de sciences comptables, Université de Sherbrooke, Sherbrooke, Canada \\ ${ }^{2}$ Samson Bélair/Deloitte \& Touche s.e.n.c.r.l., Sherbrooke, Canada \\ Correspondence: Sylvie Berthelot, Département de sciences comptables, Université de Sherbrooke, Sherbrooke, QC., \\ J1K 2R1, Canada. Tel: 1-819-821-8000 p.62003. E-mail: sylvie.berthelot@usherbrooke.ca
}

Received: March 1, 2013

Accepted: March 20, 2013

Online Published: March 21, 2013

doi:10.5430/bmr.v2n1p94

URL: http://dx.doi.org/10.5430/bmr.v2n1p94

\begin{abstract}
This study examines the sustainability content and the determinants underlying such content on Canadian oil and gas company websites. The website content of 68 of the largest oil firms listed on the S\&P/TSX was evaluated using an index based on each of the three Global Reporting Initiative (GRI) components (environmental, social and economic). The characteristics of the firms were then regressed on the content analysis. The results suggest that the larger the firm and the greater its media exposure, the more likely it is to include sustainability disclosures on its website. Firm profitability and leverage seem to be unrelated to these types of disclosures. This study provides empirical observations that could be useful for stakeholders wishing to obtain information about firms' sustainability practices and for various organizations involved in developing sustainability disclosure guidelines. The results tend to show that, despite the growing popularity of sustainability reporting benchmarks like the Global Reporting Initiative (GRI), the voluntary nature of sustainability disclosures has elicited a variety of disclosure practices on organizations' websites.
\end{abstract}

Keywords: Sustainability disclosures, Corporate social responsibility reporting, Corporate social responsibility, Websites, Corporate communication, Information technologies, Oil and gas sector, Canada

\section{Introduction}

In today's age of information technology, organizations are becoming increasingly aware of the potential "audience" that their website can reach. In recent years this popularity has coincided with growing stakeholder pressure to communicate information relating to diverse corporate sustainability issues (Herzig \& Godemann, 2010). It is therefore no surprise that organizations have responded to these expectations and that more and more companies now post information on their sites about their sustainability initiatives, performance and achievements in addition to financial information (KPMG, 2011). A website has significant advantages for a corporation; it is a relatively inexpensive medium and it makes information available to all stakeholders regardless of time and place (Herzig \& Godemann, 2010). As the information disclosed is not currently subject to any formal regulation, the firms are able to control their message and are less dependent on intermediaries like journalists and financial analysts for its dissemination (Cormier, Ledoux \& Magnan, 2009).

Since sustainability disclosures are also wholly voluntary in Canada, this study attempts to answer the following question: Do some of a firm's characteristics, such as size, media exposure, profitability and debt level, influence the sustainability disclosures it makes on its website? Sustainability disclosure content was measured using a content analysis framework based on a global GRI-based index and a separate GRI-based index for each of the three sustainability components, i.e., environmental, social and economic. Oil and gas companies were selected because they represent an important industry sector in Canada, and one that is recognized as highly polluting. This study differs from past studies in that it primarily focuses on websites' HTML content rather than on the content of sustainability reports. It also examines the question in more depth since it is aimed exclusively at a specific target sector, i.e. oil and gas companies. Finally, we used a detailed content analysis framework based on the GRI, one of the most popular sustainability reporting frameworks worldwide.

Our results show that the level of discretionary sustainability disclosures on the firms' websites is impacted by firm size and media exposure. Debt level and profitability do not seem to be relevant here. Our findings indicate a wide variety of disclosure practices among the firms studied and relatively little use of GRI guidelines. These results can be useful to users and various authorities interested in being involved in regulating corporate communication 
practices on sustainability performance.

The rest of this article is organized into several sections. It first presents the theoretical framework, commenting on previous studies. It then describes the research methodology and sample, the independent variables and the regression models used. It subsequently presents the study's results, followed by the conclusion, which sums up the main findings and outlines the study's contribution, its main limitations and potential avenues for future research.

\section{Theoretical Background}

\subsection{Disclosure determinants for sustainability reporting}

The information content of environmental reports, health safety and environmental reports and sustainability reports (also referred to as corporate social responsibility reports (Note 1)) has sparked researchers' interest for quite some time now. These reports usually contain a summary of key environmental, social and community impacts and developments relevant to understanding a company's performance and risks regarding the three recognized dimensions (environment, social and economic) of sustainable development (Leszczynska, 2012). To date, some research has focused on the content of these reports (Brammer \& Pavelin, 2004; Jose \& Lee, 2006; Stiller \& Daud, 2007; Holcomb, Upchurch \& Okumus, 2007; Bowers, 2008; Hubbard, 2011; Leszczynska, 2012), while other studies have concentrated on the determinants influencing that content (Brammer \& Pavelin, 2004; Chen \& Bouvain, 2008; Fifka \& Drabble, 2012). The results of these studies tend to show that report content varies markedly from one firm to another, and the extent of the disclosures is linked to the sector of activity, size and firm visibility (Brammer \& Pavelin, 2004), as well as to the institutional context in each country (Chen \& Bouvain, 2008; Fifka \& Drabble, 2012).

\subsection{Website benefits}

As these reports become increasingly popular (Bowers, 2010), more and more organizations are posting environmental or social information on their website. In fact, some see websites as alternative medium for corporate sustainability reporting (Herzig \& Godemann, 2010). According to Herzig \& Godemann (2010), the Internet has several advantages for sustainability reporting. It makes the information available regardless of time and place and allows the firm to communicate information that otherwise might not have been included in a sustainability report. By providing ongoing, additional or updated information, companies can respond to the greater demands of stakeholders for sustainability information (Herzig \& Godemann, 2010). The Internet also reduces the information cost, in terms of both time and money, for companies and for stakeholders alike (Herzig \& Godemann, 2010). Firms can make available data and tools that enable stakeholders to make the analysis they want (Eccles \& Krzus, 2010). In the latter authors' view, websites and other related tools also make it possible to shift from one-way information to a mutual conversation and ongoing dialogue between the firm and all of its stakeholders. It is thus certain that websites now play a larger role in corporate communication strategies and may supplant paper sustainability reports in the future (Wheeler \& Elkington, 2001). They could even prove to be a major tool for supporting the sustainable firm's culture, promoting the creation of economic, environmental and social value.

\subsection{Sustainability reporting on corporate websites}

With the growing popularity of websites as a tool for communicating corporate sustainability information, a number of studies have examined their format (Douglas, Doris \& Johnson, 2004; Capriotti \& Moreno, 2007; Koleva \& Senkel, 2010; Du \& Vieira, 2012) and the information content presented (Branco \& Rodrigues, 2006; Gill, Dickinson \& Scharl, 2008; Malarvizhi \& Yadav, 2009; Moreno \& Capriotti, 2009; Chaves et al., 2011). These studies' main conclusions reveal a significant disparity between the volume of information and its scope, communication that is essentially unidirectional and a lack of universal criteria to guarantee the reliability of the disclosures (Gill et al., 2008; Moreno \& Capriotti, 2009). The determinants underlying these types of discretionary disclosures have also attracted the interest of researchers. (Outtes Wanderly et al., 2008; Tagasson et al., 2009; Rolland \& Bazzoni, 2009; Branco \& Rodrigues, 2008; Cho \& Roberts, 2010; Gamerschlag, Moller \& Verbeeten, 2011).

As Brammer and Pavelin (2004) observed for sustainability reports, Tagesson et al. (2009), Branco \& Rodrigues (2008) and Outtes Wanderley et al. (2008) noted that the activity sector in which a company operates also influences its website disclosures. Sectors that have a potentially higher environmental impact, such as the metal, natural resources, pulp and paper, electricity production and chemicals industries, tend to make more disclosures (Tagesson et al. 2009). In a similar vein, Cho \& Roberts (2009) examined the content and presentation of the information disclosed on the websites of 76 companies in order to relate them to their environmental performance measured according to the "Toxic 100 list" (Note 2). They noted that the poorest environmental performers make more extensive disclosures in terms of website content and presentation. 
Size and media exposure have also been identified as elements affecting the environmental and social disclosures organizations make on their websites (Branco \& Rodrigues, 2008; Tagesson et al. 2009; Gamerschlag et al., 2011). Large firms tend to be under greater political and regulatory pressure from external interest groups (Gamerschlag et al., 2011). According to Gamerschlag et al. (2011), these firms disclose more information to reduce these potential political costs and to acquire and maintain their legitimacy. They also have more resources to invest in their website. As well, media exposure can explain the firms' interest in making sustainability disclosures on their websites. Companies that are closely monitored by journalists are likely to have to cope with more political and other pressure, since they attract more attention from stakeholders than less visible firms (Gamerschlag et al., 2011). Thus, if they are potentially subject to higher political costs or a higher risk of political costs, they would tend to disclose more information about their achievements to reduce such costs.

Moreover, Gamerschlag et al. (2011) and Tagesson et al. (2009) have observed that profitability seems to be tied to firms' environmental and social disclosures on their websites. Tagesson et al. (2009) see the explanation of this relationship as tied to management competencies, the fact that these disclosures can support management's position and compensation, the political costs linked to greater profitability, and the lower cost involved making website disclosures. Finally, the findings of Branco \& Rodrigues (2008) show a significant negative correlation between social responsibility disclosures and firms' leverage. However, they point out the lack of conclusiveness of past studies exploring this relationship.

\subsection{Sustainability reporting guidelines}

It is important to mention that over the past few years diverse initiatives such as the AccountAbility 1000 Series, the UN Global Compact and the Global Reporting Initiative (GRI) have also been introduced to provide guidance to organizations in making corporate responsibility disclosures. Of these, the GRI guidelines have become the guidance most widely recognized and acknowledged by corporations (Leszczynska, 2012). The global popularity and use of this guidance on the international scene has gradually underscored the diversity of the content of firms' disclosures. The GRI guidelines constitute a core content for reporting that is relevant to all organizations and provide indicator protocols to help organizations to ensure meaningful and comparable reporting on indicators (Leszczynska, 2012). These guidelines target the environmental, social and economic dimensions of sustainability.

Our study is therefore timely since it focuses on the sustainability disclosures oil and gas companies make on their websites in order to identify the main trends in light of GRI guidelines and to determine the characteristics of those companies that tend to be more committed to these types of disclosures. The aim is to provide a picture of the industry's behaviour using GRI guidelines as a lens and to contribute to the development of knowledge about the determinants underlying corporate discretionary disclosures.

\section{Methodology}

\subsection{Sample}

The Compustat database was used to compile a list of oil and gas Canadian companies listed on the Toronto Stock Exchange. It also enabled us to determine the sales, total assets, market capitalization, return on assets, and debt-equity ratio of each company. From this database, it appears that 142 Canadian companies are active in this sector and listed on the Toronto Stock Exchange. Companies with sales of under $\$ 10$ million (55 firms) were excluded from the sample, as were income trusts (12 firms) and companies acquired or merged in 2010

( 7 firms). The study thus focused on a sample of 68 active Canadian oil and gas companies listed on the Toronto Exchange. The website of each company was traced through a direct link on the Toronto Exchange site.

Note that information on corporate websites accessible through a direct link to sustainability or an annual or any other type of report included in the financial statements was not taken into consideration since the research objective was to examine only the information directly available on the corporation's website. This type of data is easily accessible and may be quickly consulted by stakeholders. The oil and gas companies were selected because they are active in an industry with a higher risk of environmental impact (Branco \& Rodrigues, 2008). As Gill et al. (2008) indicate, continual stakeholder scrutiny has encouraged these companies to adopt a "pro-active" approach to enhancing communications with their stakeholders. This activity sector in Canada is sufficiently important to obtain a sample of relatively homogenous firms of acceptable size, while reflecting some measure of difference in the size of those firms included.

\subsection{Websites' information content}

Website content was analyzed according to the GRI-based content analysis index for each of the three sustainability components. For the environmental component, we used the rating based on GRI 2002 for the environmental 
information developed by Clarkson et al. (2008). The social component was analyzed according to the social disclosures rating based on GRI 2002 Guidelines established by Sutantoputra (2008). Lastly, the economic component was assessed according to the rating of the economic component developed by Leclerc, Berthelot and Coulmont (2010) and based on GRI G3 (2006). These three sub-indices have the same analysis structure and cover the information content suggested by GRI G3 (2006) in respect of sustainability reporting.

As in the research by Clarkson et al. (2008), Sutantoputra (2008) and Leclerc et al. (2010), the information in the three sub-indices is broken down into two categories, i.e. (1) hard disclosures for information supported by tangible evidence and for which the disclosing firm may face litigation if lying and (2) soft disclosures for information with little or no substantiation (unverifiable or difficult to verify claims). The indices class the various disclosures into the following seven well-defined categories: governance structure and management systems, credibility, performance indicators, spending (except for the economic component), the firm's vision and strategies, its profile and, lastly, its initiatives. Hard disclosures make up the first four categories of items, while soft information is covered in the other three. A certain number of points are attributed for the firm's disclosures (one point per disclosure item) for each category for a possible total of 255 points. Data was collected by reading website disclosures and taking care to complete each of the three indices by granting a rating of 1 when the disclosure item according to GRI was included and 0 otherwise. Thus, the total sustainability performance is obtained from the website by totaling up the points. The websites were analyzed in the fall of 2010.

\subsection{Determinants of the sustainability disclosures}

The following four variables were considered to have a potential influence on the degree or quantity of information disclosed on corporate websites: company size, media exposure, profitability and debt level.

Size. Most researchers studying the impact of a company's size on information disclosure used total assets (SIZE $\mathrm{E}_{\mathrm{i}}$ ) as a unit of measure (Branco \& Rodrigues, 2008, Gamerschlag et al., 2011 Brammer \& Pavelin, 2004; 2006). However, to ensure that total assets are the most representative measure of company size, they were compared to the market capitalization as used by Reverte (2009) and to the sales of each of the firms in the sample. As Table 1 shows, the correlations between the different measures of size are very significant and are highly correlated with the score of discretionary sustainability disclosure $\left(\mathrm{SDSD}_{\mathrm{i}}\right)$ on the GRI-based content analysis index (including the three sub-indices). The following analyses use total assets as a measure of firm size.

Table 1. Company size / score of discretionary sustainability disclosure

\begin{tabular}{lllll}
\hline & SDSD $_{\mathrm{i}}$ & Market capitalization & Total sales & Total assets \\
\hline $\mathrm{SDSD}_{\mathrm{i}}$ & 1 & $0.874^{* *}$ & $0.844^{* *}$ & $0.875^{* *}$ \\
Market capitalization & & 1 & $0.908^{* *}$ & $0.954^{* *}$ \\
Total sales & & & 1 & $0.848^{* *}$ \\
Total assets & & & & 1 \\
\hline
\end{tabular}

**Significant correlation at 0.01 level.

Media exposure. The number of articles published in The Globe and Mail in 2009 was used to measure the media exposure $\left(\mathrm{ME}_{\mathrm{i}}\right)$ of the companies in the sample. The CPI.Q (Canadian Periodical Index) database was used to extract this information. This database provided references for articles listed in international and Canadian periodicals such as The Globe and Mail. Gamerschlag et al. (2011) used the number of hits when searching for companies' names on the most important German newspaper (in terms of business press) website. Similarly, The Globe and Mail was used as a source for media exposure since it is one of Canada's major business newspapers.

Profitability $\left(\mathrm{ROA}_{\mathrm{i}}\right)$. The profitability examined in this study was measured by the return on assets or the net profit over total assets as used by Branco \& Rodrigues (2008) and Tagesson et al. (2009).

Debt level. Although Branco \& Rodrigues (2008) used total debt over total assets; this research interprets the debt level $\left(\mathrm{DEBT}_{\mathrm{i}}\right)$ as being the long-term debt over shareholders' equity as used by Reverte (2009).

\subsection{Empirical Model}

In order to analyze the relationship between the companies' score of discretionary sustainability disclosure $\left(\mathrm{SDSD}_{\mathrm{i}}\right)$ and each of the determinants representing the independent variables presented in the previous section, a multiple linear regression model was developed. The $\mathrm{SDSD}_{\mathrm{i}}$ on the websites represents the total points (one point per GRI-based content analysis index item) with a maximum of 255 points. 
The following regression model was used:

Where,

$$
S D S D_{i}=\beta_{0}+\beta_{1} S I Z E_{i}+\beta_{2} M E_{i}+\beta_{3} R O A_{i}+\beta_{4} D E B T_{i}+\varepsilon_{i}
$$

$\mathrm{SDSD}_{\mathrm{i}} \quad$ is the score of discretionary sustainability disclosure on the GRI-based content analysis index;

SIZE $_{i} \quad$ is size of the company (total assets);

$\mathrm{ME}_{\mathrm{i}} \quad$ is media exposure;

$\mathrm{ROA}_{i} \quad$ is profitability (return on assets);

$\mathrm{DEBT}_{\mathrm{i}} \quad$ is indebtedness;

$\varepsilon_{\mathrm{i}} \quad$ is the error term.

\section{Results}

\subsection{Descriptive statistics}

The sample was made up of companies with sales of $\$ 10$ to $\$ 634$ million, the effect of size being well represented. Of the 68 companies studied, only $9(13.2 \%)$ issued a sustainability report separate from their annual report on their website. In addition, 38 companies mentioned sustainable development on their website at least once, versus 30 companies $(44.1 \%)$ that did not refer to any of the three sustainability components.

Some results of the analysis of the websites' content are particularly noteworthy. First of all, $32(47 \%)$ of the 68 companies present their social policies, values and principles, as well as the code of ethics endorsed among their managers, employees and suppliers. Furthermore, 28 firms or $41 \%$ of the sample set out their environmental policies, values and principles. As for the economic component, 16 companies or $24 \%$ present their investments and voluntary contributions to the community, while 14 or $21 \%$ mention their dividend distribution.

Table 2 contains a descriptive analysis of the study's variables. The score of discretionary sustainability disclosure relative to the websites of the sample companies ranges from 0 to 153 points of the total number of possible points of $255(60 \%)$ and the average is 14.2 points $(5.6 \%)$. It thus appears that the quantity of the information disclosed is relatively low in relation to GRI requirements. In taking a closer look at the three categories measured, it was noted that the points respecting environmental and social disclosures are relatively similar, while the economic category is far less present on the websites of the firms studied. The average points concerning environmental and social disclosure categories are $5.8(6.11 \%)$ and $5.4(6.51 \%)$, versus the average points of the economic disclosures category at $2.9(3.77 \%)$. These results can be explained by the fact that several economic information elements required by the GRI are included in the annual report or in the financial statements governed by the Canadian Securities Administrators and other economic information elements, such as the firm's infrastructure investments and services provided for the public benefit, are often also voluntarily disclosed in corporate annual reports. The firms do not seem to repeat such disclosures in their sustainability disclosures on their website. As for the firms' scores on hard and soft disclosures, the points are higher for soft disclosures in the environmental and social categories (average 1.7, or $10.63 \%$ in the environmental category and 2.1 , or $13.13 \%$ in the social category), while the same importance seems to have been awarded for hard and soft disclosures in the economic category.

Table 2. Descriptive statistic of variables

\begin{tabular}{|c|c|c|c|c|c|c|}
\hline Variables & $\mathrm{N}$ & Minimum & Maximum & Average & Standard deviation & Median \\
\hline $\operatorname{SDSD}_{\mathrm{i}}(/ 255)$ & 68 & 0 & 153 & 14.2 & 29.56 & 2 \\
\hline $\operatorname{SHDSD}_{\mathrm{i}}(/ 207)$ & 68 & 0 & 120 & 9.8 & 21.84 & 1 \\
\hline $\operatorname{SSDSD}_{\mathrm{i}}(/ 48)$ & 68 & 0 & 33 & 4.4 & 8.14 & 1.5 \\
\hline $\operatorname{SDSDenv}_{\mathrm{i}}(/ 95)$ & 68 & 0 & 63 & 5.8 & 12.64 & 1 \\
\hline $\operatorname{SHDSDenv}_{\mathrm{i}}(/ 79)$ & 68 & 0 & 50 & 4.2 & 9.48 & 0 \\
\hline $\operatorname{SSDSDenv}_{\mathrm{i}}(/ 16)$ & 68 & 0 & 13 & 1.7 & 3.13 & 0 \\
\hline $\operatorname{SDSDsoc}_{\mathrm{i}}(/ 83)$ & 68 & 0 & 54 & 5.4 & 10.67 & 1 \\
\hline SHDSDsoc $_{\mathrm{i}}(/ 67)$ & 68 & 0 & 41 & 3.4 & 7.29 & 0 \\
\hline $\operatorname{SSDSDsoc}_{\mathrm{i}}(/ 16)$ & 68 & 0 & 15 & 2.1 & 3.68 & 1 \\
\hline $\operatorname{SDSDeco}_{\mathrm{i}}(/ 77)$ & 68 & 0 & 36 & 2.9 & 6.79 & 0 \\
\hline SHDSDeco $_{i}(/ 61)$ & 68 & 0 & 29 & 2.3 & 5.43 & 0 \\
\hline $\operatorname{SSDSDeco}_{i}(/ 16)$ & 68 & 0 & 7 & 0.6 & 1.50 & 0 \\
\hline $\mathrm{SIZE}_{\mathrm{i}}($ in $\mathrm{M} \$$ ) & 68 & 96. & 69754. & 4717. & 11601. & 451. \\
\hline $\mathrm{ROA}_{\mathrm{i}}($ in \%) & 68 & -64.07 & 23.32 & -3.55 & 10.30 & -2.98 \\
\hline $\mathrm{ME}_{\mathrm{i}}$ & 68 & 0 & 118 & 6.03 & 19.52 & 0 \\
\hline DEBT $_{\mathrm{i}}($ in $\%$ ) & 68 & 0 & 255 & 33 & 49 & 17 \\
\hline
\end{tabular}


$=$ score of hard discretionary sustainability disclosure on the GRI-based content analysis index for firm i, $\operatorname{SSDSD}_{\mathrm{i}}=$ score of soft discretionary sustainability disclosure on the GRI-based content analysis index for firm i, SDSDenv $\mathrm{i}_{\mathrm{i}}=$ score of discretionary sustainability disclosure on the GRI-based content analysis index regarding environmental

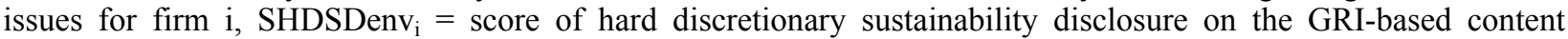

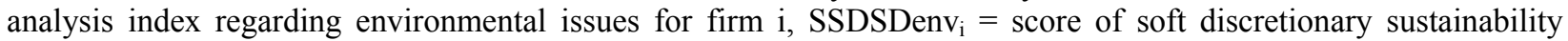
disclosure on the GRI-based content analysis index regarding environmental issues for firm i, SDSDsoc $\mathrm{i}_{\mathrm{i}}=$ score of discretionary sustainability disclosure on the GRI-based content analysis index regarding social issues for firm i, SHDSDenv $_{i}=$ score of hard discretionary sustainability disclosure on the GRI-based content analysis index

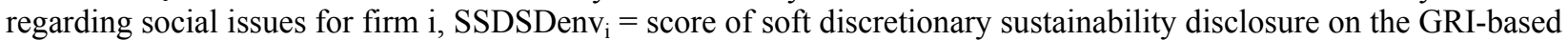

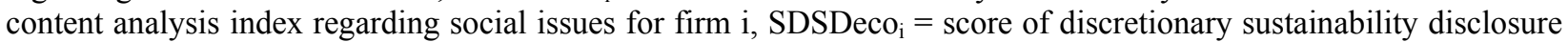

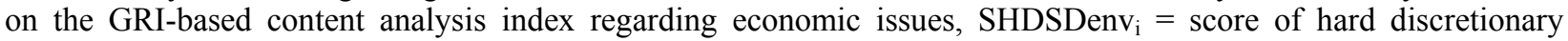
sustainability disclosure on the GRI-based content analysis index regarding economic issues for firm i, SSDSDenv $\mathrm{i}_{\mathrm{i}}=$ score of soft discretionary sustainability disclosure on the GRI-based content analysis index regarding economic issues for firm $\mathrm{i}, \mathrm{Size}_{\mathrm{i}}=$ the total assets of firm i, $\mathrm{ROA}_{\mathrm{i}}=$ the return on assets of firm $\mathrm{i}$, and $\mathrm{DEBT}_{\mathrm{i}}=$ the long-term debt over shareholders' equity ratio of firm i.

The 68 companies in the sample have total assets of between \$96M and \$69.746B, with an average of \$4.717M. Their return on assets ranges from a negative return of $64 \%$ to a positive one of $23 \%$. On average, the companies posted a negative return on assets of around $4 \%$. As for their media exposure, the number of newspaper articles in The Globe and Mail in 2009 varied from 0 to 118 with an average of 6.03 per company. Lastly, the sample is made up of firms whose debt level ranges from 0 to $255 \%$, with an average debt level of $33 \%$.

Pearson's correlations between the $\mathrm{LDSD}_{\mathrm{i}}$ obtained from analyzing the firms' website content and its components (environmental, social and economic) and the four independent variables, i.e. size (total assets), return on assets, media exposure and debt level are presented in Table 3 . The variables representing the total assets $\left(\mathrm{SIZE}_{\mathrm{i}}\right)$ and media exposure $\left(\mathrm{ME}_{\mathrm{i}}\right)$ are strongly correlated with the level of discretionary sustainability disclosure $\left(\mathrm{LDSD}_{\mathrm{i}}\right)$ (coefficients of 0.875 and 0.7750 ) and each of its components (environmental, social and economic). In contrast, the return on assets $\left(\mathrm{ROA}_{\mathrm{i}}\right)$ and the debt level $\left(\mathrm{DEBT}_{\mathrm{i}}\right)$ show low levels of correlation. Note that size and exposure appear to be strongly correlated.

Table 3. Total Disclosure Scores / Independent Variables

\begin{tabular}{lllllllll}
\hline Variables & SDSD $_{\mathrm{i}}$ & SDSDenv $_{\mathrm{i}}$ & SDSDSoc $_{\mathrm{i}}$ & SDSDeco $_{\mathrm{i}}$ & SIZE $_{\mathrm{i}}$ & ROA $_{\mathrm{i}}$ & $\mathrm{ME}_{\mathrm{i}}$ & DEBT $_{\mathrm{i}}$ \\
\hline SDSD $_{\mathrm{i}}$ & 1 & $0.99^{* *}$ & $0.99^{* *}$ & $0.96^{* *}$ & $0.88^{* *}$ & $0.27^{*}$ & $0.78^{* *}$ & 0.22 \\
SDSDenv $_{\mathrm{i}}$ & & 1 & $0.97^{* *}$ & $0.93^{* *}$ & $0.90^{* *}$ & $0.27^{*}$ & $0.80^{* *}$ & $0.24^{*}$ \\
SDSDsoc $_{\mathrm{i}}$ & & & 1 & $0.93^{* *}$ & $0.84^{* *}$ & $0.27^{*}$ & $0.70^{* *}$ & 0.21 \\
SDSDeco $_{\mathrm{i}}$ & & & & 1 & $0.83^{* *}$ & $0.27^{*}$ & $0.80^{* *}$ & 0.19 \\
SIZE $_{\mathrm{i}}$ & & & & & 1 & 0.24 & $0.84^{* *}$ & 0.23 \\
ROA $_{\mathrm{i}}$ & & & & & & 1 & 0.19 & $-0.30^{*}$ \\
ME $_{\mathrm{i}}$ & & & & & & & 1 & 0.18 \\
DEBT $_{\mathrm{i}}$ & & & & & & & & 1 \\
\hline
\end{tabular}

**Significant correlation at 0.01 level.

* Significant correlation at 0.05 level.

\subsection{Multiple Linear Regression}

Due to the presence of heteroscedasticity, a logarithmic transformation was made to the company size (LSIZE i $_{\mathrm{i}}$. Following this transformation, the remainder was distributed normally. Table 4 presents the results of the analyses carried out using the ordinary least squares method.

Table 4. Regression Analysis, Dependent Variable: $\mathrm{SDSD}_{\mathrm{i}}(\mathrm{N}=68)$

\begin{tabular}{lccccl}
\hline Dependant variables & Expected sign & SDSD $_{\mathrm{i}}$ & SDSDenv $_{\mathrm{i}}$ & SDSDsoc $_{\mathrm{i}}$ & SDSDeco $_{\mathrm{i}}$ \\
\hline LSIZE $_{\mathrm{i}}$ & $(+)$ & $8.29^{* * * *}$ & $3.52^{* * *}$ & $3.34^{* * *}$ & $1.42^{* * *}$ \\
$\mathrm{ME}_{\mathrm{i}}$ & $(+)$ & $0.74^{* * *}$ & $0.33^{* * *}$ & $0.21^{* * *}$ & $0.20^{* * *}$ \\
ROA $_{\mathrm{i}}$ & $(?)$ & -0.01 & -0.01 & -0.01 & 0.01 \\
DEBT $_{\mathrm{i}}$ & $(-)$ & -1.16 & -0.11 & -0.68 & -0.37 \\
Constant & $(?)$ & $-45.59^{* * *}$ & $-19.79^{* * *}$ & $-18.11^{* * *}$ & $-7.69^{* * *}$ \\
\hline Adjusted R & & $0.724^{* * *}$ & $0.758^{* * *}$ & $0.633^{* * *}$ & $0.705^{* * *}$ \\
\hline
\end{tabular}

$* * * \mathrm{p} \leq 0.01 ; * * \mathrm{p} \leq 0.05 ; * \mathrm{p} \leq 0.1$ (one-tailed test when the sign is predicted)

$* * * \mathrm{p} \leq 0.01 ; * * \mathrm{p} \leq 0.05 ; * \mathrm{p} \leq 0.1$ (two-tailed test when the sign is not predicted) 
The coefficients associated with log of firm size $\left(\mathrm{LSIZE}_{\mathrm{i}}\right)$ and media exposure $\left(\mathrm{ME}_{\mathrm{i}}\right)$ are positive $(8.29$ and 0.74$)$ and significant as expected. These results show that a company's size and political visibility seem to have a significant impact on its level of discretionary sustainability disclosure $\left(\operatorname{LDSD}_{\mathrm{i}}\right)$. These results are consistent with those of Tagesson et al. (2009), Branco and Rodrigues (2008) and Gamerschlag, Moller and Verbeeten (2011). However, the coefficients relating to the return on assets $\left(\mathrm{ROA}_{\mathrm{i}}\right)$ and debt level $\left(\mathrm{DEBT}_{\mathrm{i}}\right)$ do not seem relevant. Contrary to expectations, the coefficients associated with these two variables are non-significant. These results differ from those of Tagesson et al. (2009) and Gamerschlag et al. (2011) who observed in some analyses a positive significant link between a company's profitability and the level of discretionary social disclosure on its website. Moreover, our results confirm those of Reverte (2009), which demonstrate that neither profitability nor debt level seem to explain the corporations' various social responsibility communication practices. Lastly, it should be pointed out that the model explains $72.4 \%$ of the variance of the level of discretionary sustainability disclosure on the websites.

The multicollinearity between the independent variables does not appear to be problematic in this model. The variance inflation factors (VIF) associated with company size (SIZE $)$, return on assets $\left(\mathrm{ROA}_{\mathrm{i}}\right)$, media exposure $\left(\mathrm{ME}_{\mathrm{i}}\right)$ and debt level (DEBT $\mathrm{D}_{\mathrm{i}}$ ) are respectively $2.205 ; 1.525 ; 1.592$ and 1.458 , which is lower than the prescribed limit of 10 (Kutner, Nachtsheim, Neter, \& Li, 2010).

We have reviewed the analyses for each component of the SDSD, global index, i.e., the component linked to environmental $\left(\mathrm{SDSDenv}_{\mathrm{i}}\right)$, social $\left(\mathrm{SDSDSoc}_{\mathrm{i}}\right)$ and economic $\left(\mathrm{SDSDeco}_{\mathrm{i}}\right)$ disclosures. The results, which are presented in Table IV, are very similar to those set out in the model using $\operatorname{SDSD}_{\mathrm{i}}$. as a variable dependent. In fact, in each of these models, as expected, firm size (LSIZE $)_{\mathrm{i}}$ ) and media exposure $\left(\mathrm{ME}_{\mathrm{i}}\right)$ are positive and significantly related to the disclosure index and the coefficients of the variables representing firm profitability and leverage are non-significant. The adjusted $\mathrm{R}^{2}$ of these three models is significant and varies between 0.758 and 0.633 . It should be noted that the explanatory threshold of the variation is relatively high. Overall, the results seem very consistent from one model to the next. We also reviewed the analyses, breaking down the $\mathrm{SDSD}_{\mathrm{i}}$ global index and its components, $\mathrm{SDSDenv}_{\mathrm{i}}, \mathrm{SDSDsoc}_{\mathrm{i}}$ and $\mathrm{SDSDeco}_{\mathrm{i}}$ into hard and soft disclosures. The absent results are wholly consistent with those set out in Table IV.

Overall, our results tend to support the Institutional Theory (DiMaggio \& Powell, 1983). According this theory, there are various forces (social and cultural value) operating within society that cause firms' corporate reporting practices to become similar (Deegan \& Unerman, 2011). DiMaggio \& Powell (1983) identified three different isomorphic processes: coercive isomorphism, normative isomorphism and mimetic isomorphism. Coercive isomorphism relates to a change in the institutional practices of a firm due to the pressure from those stakeholders upon whom the firm is dependant (Deegan \& Unerman, 2011). Normative isomorphism stems from the adoption of a particular institutional practice by a firm due to pressure arising from group norms, as in the case of accountants and the adoption of accounting standards (Deegan \& Unerman, 2011). Finally, mimetic isomorphism occurs when a firm seeks to emulate or improve upon the institutional practices of other leading firms and thus gain greater legitimacy (Deegan \& Unerman, 2011). In noting that the voluntary sustainability disclosures of the firms are statistically related to the firms' size and media exposure, our findings corroborate the possibility that they practice mimetic isomorphism. On their websites, the Canadian oil and gas firms seems to communicate sustainability information gradually, as do the other leading firms in this sector.

\section{Conclusion}

This study examined four potential determinants of the level of discretionary disclosures on oil and gas company websites. In short, it appears that the level of discretionary disclosures on these sites is impacted by firm size and media exposure. These results confirm the conclusions of Tagesson et al. (2009), Branco \& Rodrigues (2008) and Gamerschlag et al. (2011). Furthermore, the fact that media exposure is a significant variable in the model supports the findings of Reverte (2009), which demonstrated that media exposure is the variable that most influences discretionary disclosures, followed by size and industry.

Although our study was carried out with a sample of firms involving a higher risk of environmental impact (Branco \& Rodrigues, 2008), the findings show that overall these firms disclose relatively little sustainability information on their websites, even when our study examined recent data. Given the growing use of GRI guidelines as a sustainability reporting benchmark the world over in recent years, we could have expected these disclosures to be more detailed. However, substantial differences can be observed between the minimum and maximum number of items that could be disclosed by the companies for each of the three areas covered by the GRI guidelines. In their website sustainability content analysis of North American, Asian and European oil and gas firms, Gill et al. (2008) observed that the tendency to disclose information is more prevalent among North American firms. Accordingly, 
much research and work (documentation of corporate practices, identification of stakeholder needs, identification of potential standardization, etc.) remains to be done on the international scene respecting the type of disclosure and this information intermediary. Firms do not yet seem to use their websites to their full potential as an informational intermediary.

Our findings lead us to question the extent to which these disclosures meet the needs of the firm's stakeholders. In fact, from a sustainable development perspective, firms' disclosures should meet stakeholders' needs and not necessarily be related to media exposure. This relationship to media exposure and the significant variability of the extent of disclosures tends to support the need to mandate this type of disclosure by law or regulation since it confirms the considerable discretion firms enjoy respecting the content of their sustainable reporting. Some countries, such as France and South Africa, have already taken steps in this direction. Making this type of disclosure mandatory would mean that firms would need to introduce information systems to support it. As Eccles \& Krzus (2010) point out, the assertion "What gets measured gets managed" should apply. Better information systems should lead to greater transparency and a deeper engagement with all stakeholders, better decision making and a lower reputational risk (Eccles \& Krzus, 2010). If all the firms' sustainable development disclosures were based on the same benchmarks, it would be far easier for stakeholders to interpret and analyze them. Comparisons between firms over time could be made, which would also make it easier to better evaluate firms' actual efforts.

This study has certain limitations. First, the information content of the websites was analyzed on the basis of the GRI guidelines for sustainability reporting, particularly via sustainability reports. Other initiatives supporting the communication of information on sustainable development practices, such as the UN Global Compact and the Carbon Disclosure Project, could also have been used. However, the GRI is the most comprehensive benchmark compared to these initiatives. In other words, it covers the most information elements, including environmental, social and economic sustainability components. GRI Guidelines are also strongly supported by companies and NGOs around the world (Leipziger, 2010). They are the most popular global standard. Furthermore, the interpretation of the information content of the website with the three sub-indices based on the GRI Guidelines used constitutes another limitation because of the subjective nature of the interpretation of the various criteria included in these indices. Lastly, although the sample is made up of a large share of the oil and gas companies listed on the Toronto Exchange, it is nonetheless limited to this type of firm. Further research could therefore be carried out with samples made up of companies operating in other industries in order to strengthen the study's main findings. These companies could be more critically examined from a social or economic perspective in order to determine in more detail whether the differences in website content occur because of criticism directed at the firms.

\section{References}

Brammer, S., \& Pavelin, S. (2004). Voluntary social disclosures by large UK companies. Business Ethics: A European Review, 13(2/3), 86-99. http://dx.doi.org/10.1111/j.1467-8608.2004.00356.x

Brammer, S., \& Pavelin, S. (2006). Voluntary environmental disclosures by large UK companies. Journal of Business Finance \& Accounting, 33(7 \& 8), 1168-1188. http://dx.doi.org/10.1111/j.1468-5957.2006.00598.x

Branco, M.C. \& Rodrigues, L.L. (2006). Communication of corporate social responsibility by Portuguese banks - A legitimacy theory perspective. Corporate communications: An International Journal, 11(3), 232-248. http://dx.doi.org/10.1108/13563280610680821

Branco, M.C. \& Rodrigues, L.L. (2008). Factors influencing social responsibility disclosure by Portuguese companies. Journal of Business Ethics, 83, 685-701, http://dx.doi.org/10.1007/s10551-007-9658-z

Bowers, T. (2010). From image to economic value: a genre analysis of sustainability reporting. Corporate Communications: An International Journal, 15(3), 249-252. http://dx.doi.org/10.1108/13563281011068113.

Burh, N. (2007). Histories of and rationales for sustainability reporting. In J. Unerman, J. Bebbington \& B. O' Dwyer, Sustainability Accounting and Accountability, (pp. 57-69). Abingdon, United Kingdom: Routledge.

Capriotti, P. \& Moreno, A. (2007). Communicating corporate responsibility through corporate web sites in Spain. Corporate Communications: An International Journal, 12(3), 221-237. http://dx.doi.org/10.1108/13563280710776833

Clarkson, P.M., Li, Y., Richardson, G.D., \& Vasvari, F.P. (2008). Revisiting the relationship between environmental performance and environmental disclosures: An empirical analysis. Accounting Organizations and Society, 33, 303-327. http://dx.doi.org/10.1016/j.aos.2007.05.003

Chaves, R., Mozas, A., Puentes, R. \& Bernal, E. (2011). E-corporate social reporting in socially responsible firms: 
the case of Spanish firms. The Service Industries Journal, 31(12), 2033-2050, http://dx.doi.org/10.1080/02642069.2011.545880

Chen, S. \& Bouvain, P. (2008). Is corporate responsibility converging? A comparison of corporate responsibility reporting in the USA, UK, Australia, and Germany. Journal of Business Ethics, 87, 299-317, http://dx.doi.org/10.1007/s10551-008-9794-0

Cho, C.H. \& Roberts, R.W. (2010). Environmental reporting on the internet by America's Toxic 100: Legitimacy and self-presentation. International Journal of Accounting Information Systems, 11, 1-16. http://dx.doi.org/10.1016/j.accinf.2009.12.003

Cormier, D., Ledoux, M.J., \& Magnan, M. (2009). The use of Web sites as a disclosure platform for corporate performance. International Journal of Accounting Information System, 10, 1-24. http://dx.doi.org/10.1016/j.accinf.2008.04.002

Deegan, C. \& Unerman, J. (2011). Financial Accounting Theory. Second European Edition, Berkshire, United Kingdom: McGraw-Hill Higher Education.

DiMaggio, P.J. \& Powell, W.W. (1983). The iron cage revisited: Institutional isomorphism and collective rationality in organizational fields. American Sociological Review, 48, 146-160. http://dx.doi.org/10.2307/2095101

Douglas, A., Doris, J. \& Johnson, B. (2004). Corporate social reporting in Irish financial institutions. TQM Journal, 16(6), 387-395. http://dx.doi.org/10.1108/09544780410563301

Du, S. \& Vieira, E.T. Jr. (2012). Striving for legitimacy through corporate social responsibility: insights from oil companies. Journal of Business Ethics, 110, 413-427. http://dx.doi.org/10.1007/s10551-012-1490-4

Eccles, R.G. \& Krzus, M.P. (2010). One Report Integrated reporting for a sustainability strategy. Hoboken, New Jersey: John Wiley \& Sons, Inc.

Fifka, M. S. \& Drabble, M. (2012). Focus and standardization of sustainability reporting - a comparative study of the United Kingdom and Finland. Business Strategy and the Environment, 21, 455-474, http://dx.doi.org/10.1002/bse.1730

Gamerschlag, R., Moller, K. \& Verbeeten, F. (2011). Determinants of voluntary CSR disclosure: empirical evidence from Germany. Review of Managerial Science, 2, 233-262. http://dx.doi.org/10.1007/s11846-010-0052-3

Gill, D.L., Dickinson, S.J. \& Scharl, A. (2008). Communicating sustainability - A web content analysis of North American, Asian and European firms. Journal of Communication Management, 12(3), 243-262. http://dx.doi.org/10.1108/13632540810899425

Global Reporting Initiative. (2006). Sustainability Reporting Guidelines. Amsterdam, Netherlands: Global Reporting Initiative.

Guthrie, J. \& Parker, L.D. (1989). Corporate social reporting: A rebuttal of legitimacy theory. Accounting and Business Research, 19(76), 343-352. http://dx.doi.org/10.1080/00014788.1989.9728863

Hair, J.F., Black, W.C., Babin, B.J. \& Anderson, R.E. (2010). Multivariate data analysis. Seventh Edition, Upper Saddle River, New Jersey: Prentice Hall.

Herzig, C. \& Godeman, J. (2010). Internet-supported sustainability reporting: developments in Germany. Management Research Review, 33(11), 1064-1082. http://dx.doi.org/10.1108/01409171011085903

Hogner, R.H. (1982). Corporate social reporting: Eight decades of development at US Steel. Research in Corporate Social Performance and Policy, 4, 243-250.

Holcomb, J.H., Upchurch, R.S. \& Okumus, F. (2007). Corporate social responsibility: what are top hotel companies reporting? International Journal of Contemporary Hospitality Management, 19(6), 461-475. http://dx.doi.org/10.1108/09596110710775129

Hubbard, G. (2011). The quality of the sustainability repots of large international companies: an analysis. International Journal of Management, 28(3), 824-848.

Koleva, P. \& Senkel, M.-P. (2010). Diffusion d'informations sociales et environnementales sur Internet: le cas des prestataires de services logistiques. Management International, $14 \quad$ (2), 53-68. http://dx.doi.org/10.7202/039548ar

KPMG. (2011). KPMG International Survey of Corporate Responsibility Reporting, Swiss. 
Kutner, M.H., Nachtsheim, C. J., Neter, J. \& Li, W. (2004). Applied Linear Statistical Models. Fifth Edition, New York, New York: McGraw-Hill/Irwin.

Jose, A. \& Lee, S. (2007). Environmental reporting of global corporations: a content analysis based on websites disclosures. Journal of Business Ethics, 72, 307-321. http://dx.doi.org/10.1007/s10551-006-9172-8

Leclerc, D., Berthelot, S., \& Coulmont, M. (2010). Analyse du contenu social, environnemental et économique des rapports de développement durable de sociétés canadiennes. Proceedings of the 40th Atlantic Schools of Business Annual Conference, Halifax, Nova Scotia, Canada.

Leipziger, D. (2010). The corporate Responsibility code book. Revised second edition, Greenleaf Publishing Limited, Sheffield, K.

Leszczynska, A. (2012). Towards shareholders' value: an analysis of sustainability reports. Industrial management \& data systems, 112(6), 911-928.

Malarvizhi, P. \& Yadav, S. (2009). Corporate environmental disclosures on the internet: an empirical analysis of Indian Companies. Issues in Social and Environmental Accounting, 2(2), 211-232.

Moreno, A., \& Capriotti, P. (2009). Communicating CSR, citizenship and sustainability on the web. Journal of Communication Management, 13(2), 157-175. http://dx.doi.org/10.1108/13632540910951768

Outtes Wanderly, L.S., Lucian, R., Farache, F. \& de Sousa Filho, J.M. (2008). CSR information disclosure on the Web: a context-based approach analyzing the influence of country of origin and industry sector. Journal of Business Ethics, 82, 369-378, http://dx.doi.org/10.1007/s10551-008-9892-z

Reverte, C. (2009). Determinants of corporate social responsibility disclosure rating by Spanish listed firms. Journal of Business Ethics, 88, 351-366. http://dx.doi.org/10.1007/s10551-008-9968-9

Rolland, D. and Bazzoni, J.O. (2009). Greening corporate identity: CSR online corporate identity reporting. Corporate Communications: An International Journal, 14(3), 249-263. http://dx.doi.org/10.1108/13563280910980041

Stiller, Y. \& Daub, C. (2007). Paving the way for sustainability communications: evidence from a Swiss study. Business Strategy and the Environment, 16, 474-486. http://dx.doi.org/10.1002/bse.599

Sutantoputra, A.W. (2008). Social disclosure rating system for assessing firms' CSR reports. Corporate Communications: An International Journal, 14(1) 1, 34-48.

Tagesson, T., Blank, V., Broberg, P. \& Collin, S. (2009). What explains the extent and content of social and environmental disclosures on corporate websites: A study of social and environmental reporting in Swedish listed corporations. Corporate Social Responsibility and Environmental Management, 16, 352-364. http://dx.doi.org/10.1002/csr.194

Wheeler, D. \& Elkington, J. (2001). The end of the corporate environmental report? Or the advent of cybernetic sustainability reporting and communication. Business Strategy and the Environment, 10, 1-14. http://dx.doi.org/10.1002/1099-0836(200101/02)10:1<1::AID-BSE274>3.0.CO;2-0

\section{Notes}

Note 1. Initially, the terms corporate social reporting and corporate social responsibility reporting used in earlier works (Hogner, 1982; Guthrie \& Parker, 1989) referred to social information disclosures contained in corporate annual reports. Later, the term environmental reporting was used in one-off environmental reports that were separate from annual reports (Burh, 2007). Since the early 1990s, the firms have extended the informational content to include the environmental, social and economic components of the corporate performance and sustainability report has become the more common term (Burh, 2007). However, it should be noted that the firms occasionally use other terms, such as health safety and environmental report, to describe these reports.

Note 2. The "Toxic 100" is a list of 100 companies in the United States, ranked by the amount of air pollution produced and the relative toxicity of the pollutants, as determined by the Political Economy Research Institute (PERI) at the University of Massachusetts Amherst. 